\title{
CHRISTOPHER JENSEN-BUTLER 1945/2006 ${ }^{1}$
}

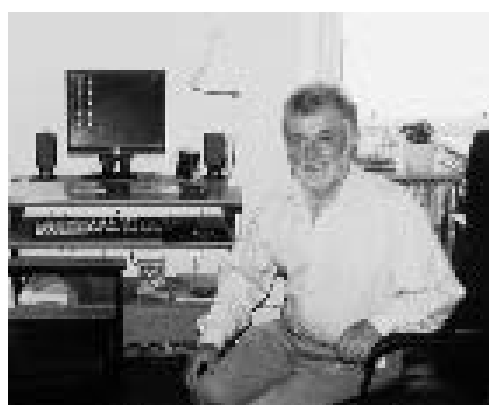

JORGE GASPAR ${ }^{2}$

Em 17 de Maio de 2006 faleceu em St. Andrews, Escócia, o Professor Christopher Jensen-Butler, geógrafo e economista de renome internacional, a quem a Geografia Económica Portuguesa muito deve e, em particular, as gerações de geógrafos formadas no Departamento de Geografia da Universidade de Lisboa ao longo de mais de duas décadas.

\section{BREVE NOTA BIOGRÁFICA}

Chris Jensen-Butler nasceu em Derby, Inglaterra, a 5 de Junho de 1945. Aí frequentou a escola, para ingressar na Universidade de Durham onde, em 1966, obteve o seu primeiro grau (BA) em Geografia e Economia, prosseguindo os estudos para o doutoramento ( $\mathrm{PhD})$, que concluiu em 1971, apresentando a dissertação An economic geography of consumer movement and expenditure patterns in County Durham.

Entre 1966 e 1969 foi assistente do Departamento de Geografia da Universidade de Durham. Em 1969 foi contratado como lektor pelo Departamento de Geografia da Universidade de Aarhus, na Dinamarca. Aí, conjuntamente com o Prof. Barry J. Garner, deu um importante contributo para a modernização e robustecimento do ensino da Geografia Humana naquela universidade dinamarquesa. É neste contexto que escreve, com Leon Dueholm, um manual de Geografia Humana, para alunos dos primeiros anos de licenciatura, dentro das orientações da Nova Geografia (Dueholm L, Jensen-Butler, C. 1975) Humangeografi - begreber og anvendelse. Gjellerup, København, 223 pp.

1 Manifestamos aqui o nosso agradecimento aos Professores Eduardo Anselmo de Castro, da Universidade de Aveiro, e Arnab Bhattacharjee, da Universidade de St. Andrews, pelas informações que nos transmitiram.

2 Professor Catedrático da Faculdade de Letras da Universidade de Lisboa. Investigador do Centro de Estudos Geográficos da Universidade de Lisboa. E-mail: jgaspar@fl.ul.pt 
A sua capacitação no domínio dos métodos quantitativos e o aprofundamento da sua formação em Matemática explicam que numa reestruturação dos estudos na Universidade de Aarhus, que teve lugar em 1988, Chris Jensen-Butler fosse convidado para leccionar no Instituto de Matemática, mantendo a sua posição de Professor Associado.

Por outro lado, Chris sempre foi atraído para as questões da decisão política na sua incidência no triângulo sociedade, economia e território. A sua capacidade e gosto por novos desafios, que aproveitava sempre para diversificar e aprofundar conhecimentos, levou-o a candidatar-se a uma posição no Instituto de Ciências Políticas da Universidade de Aarhus, onde permaneceu de 1991 a 1995. Entretanto prestava também colaboração como professor convidado de Geografia na Universidade de Copenhaga.

Depois de ter "perdido", injustamente, os concursos para o lugar de Professor (titular) de Geografia nas Universidades de Roskilde e de Copenhaga, Chris Jensen-Butler entendeu, após longa e dolorosa ponderação, que talvez fosse a altura de regressar ao Reino Unido, tendo concorrido para uma vaga de Professor no Departamento de Geografia na Universidade de St. Andrews. Lugar que obteve, mas onde permaneceu apenas um ano lectivo (1995/1996), face às orientações temáticas, metodológicas e teóricas, prevalecentes naquele departamento e com os quais não se identificava, nem encontrava pontes possíveis. $\mathrm{O}$ diferendo baseou-se na recusa da maioria dos membros do Departamento em apostar numa atitude de ligação da Geografia com o Planeamento do território e a formulação de políticas de desenvolvimento, como alternativa a abordagens meramente descritivas e especulativas.

Por interferência directa do Reitor da Universidade, com quem estabeleceu uma relação próxima e profícua desde a sua chegada a St. Andrews, Chris acabou por permanecer na histórica universidade escocesa, mas transitou para o prestigiado departamento de Economia, onde se sentia muito mais à vontade, tendo em conta as suas pesquisas nos domínios da Economia regional e urbana e da modelação matemática de fenómenos geo-económicos.

Em 1999 acabaria por ocupar a vaga de Professor na Universidade de Copenhaga e durante um ano lectivo exerceu as funções. Mas a sua vida científica e pessoal já se inclinara para St. Andrews, onde sentia o seu labor mais reconhecido. Assim, aí se manteve até ao fim da sua vida, tendo a partir de 2001 assumido as funções de Director do Departamento de Economia e em 2004 as de Director da School of Economics and Finance, com grande agrado, estima, apreço e amizade, como podemos verificar nas cerimónias fúnebres e como ficou inscrito na notícia do óbito no site do departamento: "Professor Jensen-Butler was an architect of our School's expansion and development. His personal leadership in the School was firm, yet gentle and good natured. We fear that a better leader, colleague, teacher and friend will not be found again".

Chris era homem de múltiplos interesses e conhecimentos, permanentemente utilizados no que pensava serem caminhos para um mundo melhor, o que 
o levou, por exemplo, a desenvolver, com Eduardo Anselmo de Castro, uma visão de futuro para a economia da Palestina.

Além de um docente muito activo e de muito apreciado gestor académico, Chris manteve sempre uma intensa actividade de investigação, que por vezes articulava com tarefas de consultoria. Da sua mais recente nota curricular retirámos alguma informação neste domínio:

\section{Research Interests}

1. Regional economics, regional economic modelling and policy analysis

2. Urban economic theory, urban externalities and urban policy.

3. Technology and regional and urban development, including ICT

\section{Management of and Participation in Selected Research Projects}

- Analysis of ongoing experiments with telematics in Europe. Part of EC ORA programme. For DGXIII, European Commission, together with Danish Teleconsult International A/S. Completed 1995.

- Project on evaluation of the employment effects of development of advanced telecommunications in Europe. For DGXIII, European Commission, together with Danish Teleconsult International. Completed 1995.

- Invited to present expert views on urban transport and employment to Delors' (European Commission) Cellule de Prospective. April 1994.

- Analysis of the potential environmental effects of telematics in Europe. ORA - programme on telecommunications in Europe. For DGXIII, European Commission, together with Danish Teleconsult International A/S., 1995.

- Market orientated study on advanced telecommunications in cohesion countries. For DGXIII, European Commission, with Teleconsult Danmark A/S., 1996.

- Preparation of international brochure on telematics and cities for DGXIII, European Commission. March 1996.

- Expert evaluator for projects submitted to DGXVI, European Commission: Action 2/1996: Information society pluri-regional projects. May 1996.

- Invited expert to review ongoing project on the employment effects of liberalisation in the telecommunications sector. DG V, European Commission. May 1996.

- Evaluator for DGXVI for the Regional Information Society Initiative (RISI), Rural Market Place Project, 1998.

- Evaluator for the European Commission's DGXVI ECOS-Ouverture programme (SMEs and regional development), 1999.

- Evaluator for European Regional Information Society Programme (EU, DGXIII): E-commerce and SMEs, 2000.

- Regional economic effects of the Femer Belt link (Danish Ministry of Transport), 2001. 
- Regional economic effects of road pricing for heavy vehicles in Germany (Danish Ministry of Transport), 2004.

- Member of management committee for an international research project on the regional economic effects of the Oresund Fixed Link. Led by The Royal Technical High School, Stockholm, 2000/2004.

- Member of Management Committee for TRIP (Centre for Transport Research on Environmental and Health Impacts and Policy), Danish Ministry of Transport, 2000/2004.

- Member (for Denmark) of COST 17 Management Committee (EU DGXII): SMEs and regional development, 2000/2004.

- Referee for the Economic and Social Research Council, UK and for the Norwegian Research Council.

- Member of PhD examination committees/official opponent at a number of European universities, including Copenhagen, Lund, Bergen.

- Member of national evaluation committee for Research Project proposals in Geography, Ministry of Science and Technology, Lisbon. 1993, 1999 and 2003.

\section{CHRIS JENSEN-BUTLER E PORTUGAL}

Como tantos outros intelectuais da sua geração, o interesse de Chris Jensen-Butler por Portugal inicia-se na sequência do 25 de Abril de 1974 e do processo político, social e económico que daí decorreu.

Homem de esquerda e de sólida formação marxista, não poderia ter ficado alheio à catadupa de acontecimentos que colocaram Portugal na agenda de muitos cientistas sociais, de todos os quadrantes teóricos.

A sua primeira visita foi feita à margem dos contactos entre geógrafos. Mas ainda em 1975 entrámos em contacto, tendo daí resultado um convite para visitar Aarhus em 1976 e só então verificámos que já nos tínhamos encontrado em Lund em 1973, aquando de um colóquio sobre os mapas mentais dos europeus, organizado por T. Hägerstrand e Peter Gould e em que também participou Chris, bem como Barry Garner.

É nos finais dos anos 1970 que inicia a colaboração ao Centro de Estudos Geográficos e ao Departamento de Geografia da Universidade de Lisboa (U.L.), quer apoiando investigações em curso, quer através de algumas sessões de seminários. Mas essa colaboração atingirá uma significativa expressão na década seguinte, tendo lugar uma verdadeira integração na então EPRU (Linha de Acção Estudos para o Planeamento Regional e Urbano), bem como uma participação regular no Mestrado em Geografia Humana e Planeamento Regional e Local, sobretudo a partir do momento em que se iniciou o Programa Erasmus, em que o Departamento de Geografia da U. L. foi pioneiro, propondo-se coordenar uma rede em que participavam também as universidades de Copenhaga, Barcelona e Genebra. 
Foi sobretudo através da colaboração regular naquele mestrado que Chris teve uma influência determinante, não só nos pósgraduados pelo Departamento de Geografia da U.L., mas também em vários docentes, em cujo número me incluo, e a partir daí na teoria e na prática da Geografia Humana e do Planeamento Regional que se foi fazendo em Portugal, em particular em teoria, análise e políticas de desenvolvimento regional.

Valiosa e com grande alcance científico e técnico foi a participação de Chris nalguns projectos de investigação, contribuindo de forma decisiva para os resultados conseguidos. O primeiro, que obteve o apoio da Fundação Luso-Americana para o Desenvolvimento e da Comissão de Coordenação da Região Centro, foi pioneiro em Portugal na abordagem do papel das telecomunicações no desenvolvimento regional e urbano. As pesquisas, em que cooperaram as Universidades de Lisboa e de Aarhus e em que participaram também técnicos daquela Comissão de Coordenação, contemplaram casos de estudo em Portugal, nas áreas de Leiria - Marinha Grande, de Castelo Branco e da Cova da Beira, e na Dinamarca. Além de relatórios com orientações de políticas de desenvolvimento regional, foram produzidos e publicados alguns artigos em revistas científicas.

Seguiu-se a participação no programa de investigação prospectiva, de natureza multidisciplinar promovido pela Fundação Calouste Gulbenkian (FCG), coordenado pelo Doutor João Caraça: Portugal - os Próximos 20 Anos. A equipa do CEG-UL, coordenada pelo autor desta nota, teve em Chris não só um pilar fundamental para o desenvolvimento de ferramentas adequadas à metodologia escolhida (com relevo para o modelo REX, que Chris e Diogo Abreu viriam a aperfeiçoar em posteriores aplicações), como um estimulante animador de inúmeras sessões de reflexão/discussão sobre os possíveis futuros do território português. Entre outros resultados, sublinhe-se a publicação de dois livros na série que a FCG dedicou ao Programa.

A partir da segunda metade dos anos 1990, embora mantendo uma colaboração regular com o Departamento de Geografia da U.L., Chris aprofundou as relações com a Universidade de Aveiro, na sequência da cooperação com Eduardo Anselmo de Castro, seu estudante de mestrado no Departamento de Geografia em Lisboa e de doutoramento na Universidade de Copenhague, com quem manteve até ao final da vida continuada actividade de investigação conjunta; referimos, por conhecermos melhor o projecto, Telecommunications and competitiveness of productive systems: the case of the District of Aveiro, realizado no âmbito do Programa PRAXIS XXI. Encadeado com este trabalho, participou em 1996, como perito subcontratado pela Teleconsult Danmark, no projecto MOSAICC, encomendado pela DG III da Comissão Europeia, que estudou os efeitos da liberalização das telecomunicações nas regiões periféricas dos países da coesão, tendo trabalhado em estreita colaboração com a equipa da Universidade de Aveiro.

Chris também desenvolveu trabalho de consultoria em Portugal no domínio do planeamento regional e urbano. Do que conhecemos, destacamos a par- 
ticipação no Estudo Preparatório da Operação Integrada de Desenvolvimento (OID) da Península de Setúbal, muito criativa e inovadora, e o valioso contributo para estudos preparatórios do 2. ${ }^{\circ} \mathrm{QCA}$. Em qualquer dos casos Chris antecipou processos de transformação do território e fez propostas, muitas delas perdidas mas ainda com actualidade.

À primeira vista Chris não tinha grande propensão para o tradicional "trabalho de campo", mas essa aparente fraqueza era superada pelo gosto imenso de viajar, de empreender grandes caminhadas e a tudo se sobrepunha a navegação à vela.

No entanto, tivemos a oportunidade de fazer algumas visitas de estudo com Chris e foram sempre experiências muito gratificantes. De todas, destacamos a visita ao Reino Unido em 1987 para observar um conjunto de experiências em curso em áreas industriais em declínio onde se ensaiavam várias experiências em diversos domínios do planeamento e do ordenamento do território. Esta visita, em que também participou Mendes Baptista, teve lugar no âmbito da preparação do Estudo Preparatório da OID da Península de Setúbal.

Foi pelo conhecimento dos enormes méritos científicos, que até muito tarde não tiveram o devido reconhecimento internacional (incluindo na Dinamarca), que quando fomos convidados para integrar o grupo dinamizado por Sture Oberg e Arie Sachar, que lançou o programa RURE (Regional and Urban Restructuring in Europe) no âmbito da European Science Foundation, logo propusemos o nome de Chris Jensen-Butler, imediatamente aceite. Em boa hora, pois viria a dar uma dos principais contribuições para o sucesso do programa.

\section{UM HOMEM DE CULTURA E UM CIDADÃO A TEMPO INTEIRO}

Chris Jensen-Butler era dotado de uma vastíssima cultura humanista, decorrente não só de uma sólida formação académica, como de uma prática de vida, aberta ao Mundo - das Letras e das Artes, das Ciências e das Técnicas.

Conhecendo-lhe esta dimensão maior da sua personalidade, mais facilmente se chegava à compreensão do que mais impressionava no seu carácter e na sua prática: Chris era um homem moral - na forma como valorizava as pessoas e as coisas, na sua maneira de fazer ciência e de colocar os resultados ao serviço da comunidade, na bondade e tolerância da sua exigente pedagogia.

Porque era bom e gostava de fazer bem, Chris sabia distinguir a qualidade e, por isso, gostava das coisas boas desta vida: os livros, as músicas, as comidas, as bebidas, o desenho e a pintura, os lugares.

Cientista mais voltado para as questões da Economia e da sociedade que abordava privilegiadamente através da Matemática, nem por isso esquecia a importância dos lugares, cada um com as suas dimensões próprias.

Por tudo isto, Chris gostava da paisagem e também das suas representações. Um gostar feito de combinações analíticas e de apreensões poéticas. Assim se perceberão as suas tendências contemplativas e as preocupações ambientais: 
questão em relação à qual era, a um tempo, apaixonado e rigoroso - sempre de sobreaviso em relação aos posicionamentos ideológicos.

Claro que nunca podemos separar o ser humano do cidadão, mas na praxis política de uma vida, feita de tempos longos e também de dias que se seguem com a inexorável regularidade do movimento astronómico, é importante saber fazer as distinções. Chris sempre o soube, nos conceitos e nas práticas. Homem de Esquerda e de Partido(s), teve uma dedicada e eficiente actividade sindical, que de modo algum prejudicou a sua actividade pedagógica e científica. Eram esferas diferentes, que só se tocavam no desígnio de fazer melhor, na dimensão moral a que nos referimos.

Foi esse Homem, rico na pluralidade, amoroso das gentes e dos lugares, sereno e tolerante, honestamente crítico, que nos foi faltando, pouco a pouco, no curto e acelerado Outono de uma vida que se precipitou. E desse Homem que sentimos uma saudade angustiante, mas cuja memória, feita de encontros e de ausências, nos irá ajudar a ajudar.

\section{ALGUMAS PUBLICAÇÕES RECENTES}

\section{Artigos em revistas internacionais com referee:}

Castro E A, Jensen-Butler C N (2003) Demand for information and communication technology-based services and regional economic development. Papers in Regional Science, 82(1): 27-50.

Castro E A, Jensen-Butler C (1999) Malthus Revisited. The Economics and Politics of Sustainable Development. In Benhayoun G, Gaussier N, Planque B (eds) L'Ancrage Territorial du Développement Durable: de Nouvelles Perspectives. L'Harmattan, Paris: 27-58.

Engelstoft S, Jensen-Butler C N, Smith I, Winter L (2005) The economics of industrial clusters. The case of Denmark. To be published in: Papers in Regional Science, 2006.

Gaspar J, Jensen-Butler C N (1992) Social, Economic and Cultural Transformations in the Portuguese Urban System. International Journal of Urban and Regional Research, 16(3): 442-461.

Hansen F, Jensen-Butler C N (1996) Economic crisis and the regional and local economic effects of the welfare state: The case of Denmark. Regional Studies, 30(2): 167-187.

Jensen-Butler C N (1999) Cities in competition: Equity issues. Urban Studies, 36(5-6): 865-891.

Jensen-Butler C N (1992) Rural Industrialization in Denmark and the Role of Public Policy. Urban Studies, 29(6): 881-904.

Jensen-Butler C N, Madsen B (2005) Decomposition analysis: an extended theoretical foundation and its application to the study of regional income growth in Denmark. Environment \& Planning A, 37(12): 2189-2208.

Jensen-Butler C N, Geremia M, de Castro E A (2001) The environment and the economy: spatial issues and spatial perspectives. International Journal of Environmental Technology and Management, 1(3): 209-231.

Jensen-Butler C N, Madsen B (1999) An eclectic methodology for assessment of the regional economic effects of the Femer Belt link between Scandinavia and Germany. Regional Studies, 33(8): 751-768. 
Jensen-Butler C N, Madsen B (1996) Modelling the regional economic effects of the Great Belt link. Papers in Regional Science, 75(2): 1-21.

Madsen B, Jensen-Butler C N (2005) Spatial accounting methods and the construction of spatial Social Accounting Matrices. Economic Systems Research, 17(2): 187-210.

Madsen B, Jensen-Butler C N (2004) Theoretical and operational issues in sub-regional economic modelling, illustrated through the development and application of the LINE model. Economic Modelling, 21(3): 471-508.

Madsen B, Jensen-Butler C N, Zhang J (2003) Regional economic impacts of traffic regulation on tourism: The case of Denmark. Review of Urban and Regional Development Studies, 15(2): 148-170.

Madsen B, Jensen-Butler C N (1999) Commodity balance and regional trade: Make and use approaches to interregional modelling. Economic Systems Research, 11(3): 277-299.

Madsen B, Jensen-Butler C N (1997) The regional economic effects of major transport infrastructure investments: the Danish case. International Journal of Development Planning Literature, $12(2)$.

\section{Livros e capítulos de livros}

Jensen-Butler, C N (1996) A theoretical framework for analysis of urban economic policy. In Lever W F, Bailly A (eds) The spatial impact of economic changes in Europe. Avebury, Aldershot: 251-293.

Jensen-Butler C N, Madsen B (2005) Transport and regional growth. In Button K J, Hensher D A (eds) Handbook of transport strategy, policy and institutions, Handbooks in Transport Vol. 6. Elsevier, Amsterdam: 191-224.

Jensen-Butler C N, Madsen B (2002) Modelling the regional economic effects of the Danish Great Belt Link. In Stough R, Vickerman R, Button K, Nijkamp P (eds) Classics in Transport Analysis, vol. 4, Transport Infrastructures. Edward Elgar, Williston, Vermont: 615-635.

Jensen-Butler C N, Madsen B, Caspersen S (2002) Rural areas in crisis? The role of the welfare state in income creation: The case of Denmark. In Johansson B, Karlsson C, Stough R (eds) Regional policies and comparative advantage. Edward Elgar, Cheltenham: 323-363.

Jensen-Butler C N, Shachar A,Van Weesep J (eds) (1997) European cities in competition. Avebury.

Madsen B, Jensen-Butler C N (2003) Accounting and modelling SMEs in the regional economy. In Fingleton B, Eraydin A, Paci R (eds) Regional economic growth, SMEs and the wider Europe. Ashgate, Aldershot: 129-148.

Madsen B, Jensen-Butler C N (2002) Regional economic modelling in Denmark: construction of an interregional SAM with data at high levels of disagregation, subject to national constraints. In Hewings G J D, Sonis M, Boyce D (eds) Trade, networks and hierarchies. Modeling regional and interregional economies. Springer Verlag, Berlin: 445-456.

Madsen B, Jensen-Butler C N, Birch Mortensen J, Bruun-Christensen A M (eds) (1996) Modelling the economy and the environment. Springer-Verlag, Berlin.

\section{Algumas publicações relacionadas com Portugal}

Abreu D, Costa N, Gaspar J, Jensen-Butler C (1991) A evolução sócio-económica regional e a introdução de comboios de grande velocidade em Portugal. OPEUR/GEP MOP, Lisboa.

Abreu D, Jensen-Butler C N (1987) The Multiplicative Effects of Regional Investment in Portugal. Report prepared for the Ministry of Planning, Lisbon, Notat 66, 1987, Geografisk Institut, Aarhus Universitet. 
Abreu D, Jensen-Bulter C N (1985) LISCLUST: An hierarchical cluster analysis program. With application to a socio-economic analysis of portuguese municipalities. Geographical Institute, University of Aarhus, Denmark.

Abreu D, Jensen-Butler C N, et al (1991) Monitoring the effects of the community support framework for Portugal. CEDRU Lisbon.

Boura I, Gaspar J, Jacinto R, Jensen-Butler C N (1987) Implementação de um projecto: criação de NTI nos sectores produtivos, no contexto do desenvolvimento regional. Desenvolvimento Regional, no. 24/25, Coimbra, CCR Centro.

Ferrão J, Jensen-Butler C N (1986) Industrial structure and regional development in Portugal. Tijdschrift voor Economische en Sociale Geografie, 1 (2): 17.

Ferrão J, Jensen-Butler C N (1986) Desenvolvimento Industrial e diferenciações regionais em Portugal, durante a década de 70. Finisterra - Revista Portuguesa de Geografia, XXI (42): 203-238.

Ferrão J, Jensen-Butler C N (1984) The centre-periphery model and industrial development in Portugal. Environment \& Planning D, 2: 28.

Gaspar J, Jensen-Butler C N (1988) As telecomunicações e a localização de Portugal no espaço informativo global. Finisterra - Revista Portuguesa de Geografia, XXIII (46): 189-224.

Gaspar J, Jensen-Bulter C N, Jeppesen S E (1986) Telecomunicações e desenvolvimento regional em Portugal: Um projecto para a região Centro. Finisterra - Revista Portuguesa de Geografia, $\mathrm{XXI}(41): 5-56$.

Jensen-Butler C N, Abreu D, Serrão J, Gaspar J (1989) Portugal nos próximos 20 anos, $2{ }^{\circ}$ vol.: A Ocupação e a Organização do Espaço, Lisbon, Fundação Calouste Gulbenkian.

Jensen-Butler C N, Gaspar J, (1989) Telecomunications and the location of Portugal in global information space - 1950-1985. Geografisk Tidsskrift, 90: 18-28.

Jensen-Butler C N (1986) Telecommunications and regional development in Portugal. (with Gaspar, $\mathrm{J}$ and Erik Jeppesen, S). Arbejdsrapport (16), Aarhus Universitet.

Jensen-Butler C N (1986) Indústria e valorização do capital. Uma análise geográfica de João Ferrão. Finisterra - Revista Portuguesa de Geografia, XXI (42): 347-352.

Jensen-Butler C N (1988) Telecommunications and the location of Portugal in global information space. (with Gaspar, J). NOTAT, 69, Geografisk Institut, Aarhus Universitet.

Jensen-Butler C N (1986) Construction of regional and interregional input-output tables for portuguese regions. A technical Report. Unpublished paper.

Jensen-Butler C N (1984) Portugal og EF. Geografisk Orientering, 3(10): 9.

Jensen-Butler C N, Pires I M M (1993) Industrial structure and regional development in Portugal. Working Paper, no. 13, Geographical Institute, University of Aarhus, Denmark. 